NOTA CIENTÍFICA

Note on the diet of Ameiva edracantha (Squamata, Teiidae) in Cerros de Amotape National Park, Tumbes, Peru

\title{
Nota sobre la dieta de Ameiva edracantha (Squamata, Teiidae) en el Par- que Nacional Cerros de Amotape, Tumbes, Perú
}

\author{
Juan C. Jordán ${ }^{1,2}$ and Diana Amaya ${ }^{1}$
}

1 Departamento de Herpetología, Museo de Historia Natural, Universidad Nacional Mayor de San Marcos, Museo de Historia Natural, Universidad Nacional Mayor de Universidad Nacional Mayor de San Marcos. Av. Arenales 1256, Jesús María 14, Perú.

2 Laboratorio de Estudios en Biodiversidad (LEB) . Departamento de Ciencias Biológicas y Fisióógicas. Clencias Blologicas yioricas. acultad de Ciencias y Filosofia. Heredia (UPCH).

Email Juan Carlos Jordán: juan.jordan@gmail.com

\section{Presentado: $\quad 13 / 12 / 2010$} Aceptado: $\quad 11 / 07 / 2011$

Publicado online: 25/08/201

\begin{abstract}
The diet of Ameiva edracantha Bocourt 1874, a terrestrial diurnal teiid lizard distributed in northwestern Peru and southwestern Ecuador is described for the first time. Stomach contents of fifteen individuals collected from quebrada La Angostura were analyzed. Lepidopteran larvae, coleopterans, orthopterans and spiders were the dominant preys in the lizard's diet. Snout-vent length and head length, width and height were not correlated to prey length, width and volume. Other parameters such as profitability and prey target selection could be involved in prey selection by $A$. edracantha.
\end{abstract}

Keywords: lizard diet; dry forests; Cerros de Amotape National Park; Ameiva edracantha.

\section{Resumen}

Se describe por primera vez la dieta de Ameiva edracantha, una especie de lagartija teiida diurna terrestre que se distribuye en la costa noroeste de Perú y suroeste de Ecuador. Se analizó el contenido estomacal de 15 individuos colectados en la quebrada La Angostura. La dieta de $A$. edracantha estuvo compuesto principalmente por larvas de lepidópteros, coleópteros, ortópteros y arañas. La longitud hocico-cloaca y la longitud, ancho y alto de la cabeza no se relacionó con la longitud, ancho y volumen de las presas. Otros parámetros como selección específica de presas y profitabilidad, podrían estar involucrados en la selección de presas en $A$. edracantha.

Palabras clave: dieta de saurios; bosques secos; Parque Nacional Cerros de Amotape; Ameiva edracantha.

\section{Introduction}

The genus Ameiva comprises 32 currently recognized species distributed in Central and South America (Hower \& Blair 2003). In Peru, four species of Ameiva lizards occur: $A$. ameiva, A. bifrontata, $A$. edracantha and $A$. septemlineata, with the last two occuring inside Cerros de Amotape National Park. Ameiva edracantha Bocourt, 1874, is a medium-sized teiid lizard (Jordán 2010) distributed in northwestern Peru and southwestern Ecuador. Ameiva edracantha has been registered in dry and tropical Pacific forest at northwestern Peru (Carrillo \& Icochea 1995, Jordán 2010) and in dry bushes and lomas in central Peru (Lehr 2002, Aguilar et al. 2007).

Here, we present for first time data on the diet of Ameiva edracantha from the dry forests inside Cerros de Amotape National Park in northwestern Peru.

\section{Material and methods}

The study was carried out at the surroundings of La Angostura rural village and Quebrada La Angostura (S 03\%45'14.4”W 080'23'17.9'W, $70 \mathrm{~m}$ of altitude), near the control post of the Servicio Nacional de Áreas Naturales Protegidas (SERNANP), inside Cerros de Amotape National Park during February, 2005 (rainy season).

The study area is mostly composed of low dense xerophiticspiny bushes ("matorral deciduo", Aguirre et al. 2006), represented by Prosopis pallida, Prosopis juliflora, Acacia macracantha, Capparis scabrida, C. crotonoides, C. avicenniifolia, Caesalpinia glabrata, Ipomoea carnea, Cordia lutea, Armatocereus cartwrightianus among others (Aguirre et al. 2006, Linares-Palomino, 2006).
Fifteen adult individuals (as recognized for their sexual coloration and gonadal development) were hand-or noose-collected. Snout-vent length (SVL) head length (HL), width (HW) and height $(\mathrm{HH})$ were measured with a vernier caliper $(0.02 \mathrm{~mm})$. Lizards were kindly sacrificed with Ketalar injection $(0.2 \mathrm{~mL})$, dissected and their stomach content removed and stored in $70^{\circ}$ alcohol in field.

Specimens were deposited in the Department of Herpetology collection at Museo de Historia Natural, Universidad Nacional Mayor de San Marcos (MUSM).

Stomach contents were analyzed, items identified to the order level (following Borror et al. 1992) and measured (length and width) in the Laboratory of Entomology (MUSM), with a stereoscopic microscope.

Normality of lizard morphological variables was assessed with a Kolmogorov-Smirnov test, then, sex-differences in size were assessed with a t-test. Lizard morphological variables and prey measurements were $\log _{10}$ transformed to normalize its distribution and analyzed with a linear regression to determine a possible correlation between these two variables sets.

Trophic niche breadth was calculated with the inverse Simpson diversity index (Pianka 1973, Vitt \& Zani 1996):

$$
\mathrm{B}=1 / \sum\left(\rho \mathrm{i}^{2}\right)
$$

Where $\rho$ is the proportion of the $i$ resource (preys in this case). Niche breadth vary from 1 (use of one prey) to $n$ (use of all preys). 
Table 1. Morphological measurements variables of Ameiva edracantha

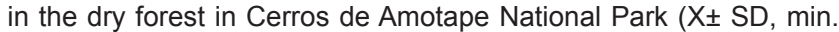
and max. range values).

\begin{tabular}{lccc}
\hline Ameiva edracantha & X \pm DS (mm) & min. & max. \\
\hline Snout-vent length (SVL) & $68.38 \pm 7.97$ & 53.3 & 77.4 \\
Head length (HL) & $17.4 \pm 2.96$ & 13.1 & 22.5 \\
Head width (HW) & $9.71 \pm 1.76$ & 6.9 & 13.2 \\
Head height (HH) & $7.79 \pm 1.38$ & 5.3 & 9.8 \\
\hline
\end{tabular}

\section{Results}

The smallest individual collected measured $53.3 \mathrm{~mm}$ while the largest measured 77.4 mm of SVL. Morphological measurements are presented in Table 1 . Because no differences in size between sexes were registered $(D=0.5 ; p=0.21)$, we combined all data for subsequent analysis.

The diet of Ameiva edracantha consists of 8 different prey types. Numerically, lepidopteran larvae (39.1\%), coleopterans $(17.3 \%)$ and orthopterans $(15.2 \%)$ were the most consumed prey items by this lizard (Table 2). The most frequent prey items in lizard stomachs were lepidopteran larvae, coleopterans

Table 2. Diet of Ameiva edracantha in the dry forest of Cerros de Amotape National Park (Tumbes, Peru). Categories are based on order level (Borror et al. 1992).

\begin{tabular}{lcccc}
\hline Prey type & N & N\% & F & F\% \\
\hline Aranae & 5 & 10.9 & 4 & 26.7 \\
Coleoptera & 8 & 17.4 & 8 & 53.3 \\
Formicidae & 1 & 2.2 & 1 & 6.7 \\
Homoptera & 1 & 2.2 & 1 & 6.7 \\
Lepidoptera & 3 & 6.5 & 3 & 20.0 \\
Orthoptera & 7 & 15.2 & 7 & 46.7 \\
Lepidoptera (larvae) & 18 & 39.1 & 8 & 53.3 \\
Coleoptera (larvae) & 3 & 6.5 & 3 & 20.0 \\
Trophic niche breadth (Bt) & 4.41 & & & \\
\hline
\end{tabular}

(presented in 53.3\% of all stomachs) and orthopterans (46.6\%) (Table 2). Trophic niche breadth $\left(\mathrm{B}_{\mathrm{t}}\right)$ of Ameiva edracantha, calculated from numeric occurrence of prey, was 4.41 (Table 2).

Prey averaged $13.5 \pm 7.31 \mathrm{~mm}$ in length (range $4-28 \mathrm{~mm}$ ); $2.96 \pm 1,53 \mathrm{~mm}$ in width (range $0.5-6 \mathrm{~mm}$ ); and $99.08 \pm$ $120.90 \mathrm{~mm}^{3}$ in volume $\left(0.52-395.84 \mathrm{~mm}^{3}\right)$ (Table 3$)$. The number of prey per lizard varied from $1-7$ (mean: $3.53 \pm 2.02$ ) (Table 3). There were no correlation between lizard SVL and mean prey length $\left(\mathrm{R}^{2}=0.088 ; \mathrm{F}_{1,13}=0.10 ; \mathrm{p}=0.75\right)$, mean prey width $\left(\mathrm{R}^{2}=0.05 ; \mathrm{F}_{1,13}=0.82 ; \mathrm{p}=0.37\right)$ and mean prey volume $\left(R^{2}=0.013 ; F_{1,13}=0.18 ; p=0.67\right)$. In a similar way, there were no

Tabla 3. Descriptive statistics of prey items consumed by Ameiva

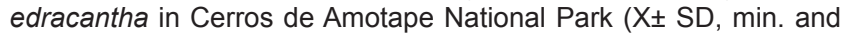
max. range values).

\begin{tabular}{cccc}
\hline Preys & $\mathbf{X} \pm$ SD $(\mathbf{m m})$ & mín. & máx. \\
\hline Prey ítems categories (order) & 6 & & \\
Prey number & 33 & & \\
Prey per stomach & $3.53 \pm 2.02$ & 1 & 7 \\
Prey lenght $(\mathbf{m m})$ & $13.5 \pm 7.31$ & 4 & 28 \\
Prey width $(\mathbf{m m})$ & $2.96 \pm 1.53$ & 0.5 & 6 \\
Prey volume $\left(\mathbf{m m}^{3}\right)$ & $99.08 \pm 120.90$ & 0.52 & 395.84 \\
\hline
\end{tabular}

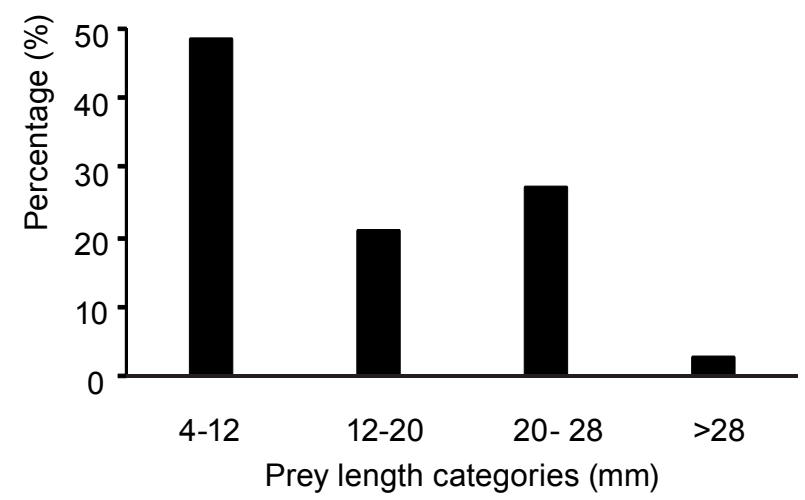

Figure 1. Percentage of prey length categories $(\mathrm{mm})$ consumed by Ameiva edracantha in Cerros de Amotape National Park.

correlation between lizard head length and mean prey volume $\left(\mathrm{R}^{2}=0.005 ; \mathrm{F}_{1,13}=0.066 ; \mathrm{p}=0.80\right)$, head width and mean prey volume $\left(\mathrm{R}^{2}=0.001 ; \mathrm{F}_{1,13}=0.02 ; \mathrm{p}=0.88\right)$ and head height and mean prey volume $\left(\mathrm{R}^{2}=0.0001 ; \mathrm{F}_{1,13}=0.002 ; \mathrm{p}=0.96\right)$.

Aditionally, preys were arbitrarily classified in four broad size categories: a $(4-12 \mathrm{~mm}), \mathrm{b}(12-20 \mathrm{~mm}), \mathrm{c}(20-28$ $\mathrm{mm})$ and d (>28 mm). Ameiva edracantha consumes prey of all size categories with higher consumption frequency of a and c categories (48.5\% and $27.3 \%$, respectively; Fig. 1), with larvae accounting for this variation mainly.

\section{Discussion}

Teiids are active foragers, usually capturing hidden or lumped preys (Huey \& Pianka 1980) detected by chemical cues (Cooper 1990, 1994, 1995). Ameiva edracantha presents an active foraging strategy, covering wide areas while searching for preys under leaf-litter or tree and rock holes in the study area.

Ameiva edracantha could be considered as a generalist forager in the dry forest of Cerros de Amotape National Park based on its trophic niche breadth, comparable to other peruvian coastal lizards as Phyllodactylus reissi (Jordán 2006), Microlophus peruvianus (Pérez \& Balta 2009) Microlophus tigris (Pérez 2005). Lepidopteran larvae, coleopterans, orthopterans and spiders are the main prey items of the diet of $A$. edracantha, similar to its diet in adyacent Tropical Pacific Forest (Jordán 2010) and to other Ameiva species, such Ameiva festiva (Vitt \& Zani 1996), Ameiva ameiva (Vitt \& Colli 1994, Vitt et al. 2000), Ameiva septemlineata (Jordán 2010) and with other related genus as Kentropyx (Vitt et al. 1994, Vitt et al. 2001) and Cnemidophorus (Mesquita \& Colli, 2003, Menezes et al. 2006).

Lizard body size and head dimensions are usually related to prey size and/or volume (Schoener 1967, Vitt et al. 1996, Vitt \& Zani 1998 a,b, Vitt et al. 2000). However, in some species, this relationship is not apparent as in the teiid Cnemidophorus deepii (Vitt et al. 1993) and the tropidurid Tropidurus oreadicus (Rocha \& Siqueira 2008), similar to results reported here for $A$. edracantha in northwestern dry forests.

Apparently, Ameiva edracantha does not necessarily select preys based on size (or volume), as has been recorded for other Ameiva species (Vitt \& Colli, 1994, Vitt \& Zani, 1996, Vitt et al. 2000) and other teiids (Vitt et al. 1994, Vitt et al. 2000, 
Vitt et al. 2001). Other parameters, such as net profitability and prey target selectivity (Costa et al. 2008), related to its foraging mode could be involved in this result.

Dry forests are a unique and high endangered ecosystem (García-Villacorta et al. 2009). More detailed ecological studies on this lizard and the sympatric saurian community, as well as their interaction with other taxa, are needed to gain more insights into the dynamics of this fragile area.

\section{Acknowledgements}

JCJ thanks to all the people at La Angostura village for their kind support and to Cerros de Amotape National Park staff for granted collection permit (former Instituto Nacional de Recursos Naturales, actually Servicio Nacional de Áreas Naturales Protegidas). Also, we thank César Aguilar and Karen Siu-Ting for their critical comments on earlier draft of this manuscript.

\section{Literature cited}

Aguilar C., M. Lundberg, K. Siu-Ting y M. Jiménez. 2007. Nuevos registros para la herpetofauna del Departamento de Lima, descripción del renacuajo de Telmatobius rimac Schmidt, 1954 (Anura: Ceratophrydae) y una clave de los anfibios. Revista Peruana de Biología. 14 (2): 209-216

Aguirre Z., R. Linares-Palomino \& L. Kvist. 2006. Especies leñosas $\mathrm{y}$ formaciones vegetales en los bosques estacionalmente secos de Ecuador y Perú. Arnaldoa. 13(2):324-350.

Borror D.J., C.A. Triplehorn \& N.F. Johnson. 1992.An introduction to the study of insects. Sixth Edition. Saunders College Publishing, $875 \mathrm{pp}$

Carrillo N. \& J. Icochea.1995. Lista taxonómica preliminar de los reptiles vivientes del Perú. Publicaciones del Museo de Historia Natural, UNMSM (A) ,49:1-27.

Cooper, W. E., Jr. 1990. Prey odor detection by teiid and lacertid lizards and its relationship to foraging mode in lizard families. Copeia 1990:237-242

Cooper, W. E., Jr. 1994. Prey chemical discrimination, foraging mode, and phylogeny. Pp. 95-116, In E. R. Pianka and L. J. Vitt (eds.), Lizard Ecology: Historical and Experimental Perspectives. Princeton University Press, Princeton.

Cooper, W. E., Jr. 1995. Foraging mode, prey chemical discrimination, and phylogeny in lizards. Animal Behaviour 50:973-985.

Hower L. \& B. Hedges. 2003. Molecular Phylogeny and Biogeography of West Indian Teiid lizards of the Genus Ameiva. Caribbean Journal of Science. 39(3):298-306

Huey R. \& E.R. Pianka. 1981. Ecological consequences of foraging mode. Ecology. 62(4): 991-999

Jordan J.C. 2006. Dieta de Phyllodactylus reissi (Sauria: Gekkonidae) en la Zona Reservada de Tumbes, Peru. Revista Peruana de Biologia. 13(1):121-123

Jordán J.C. 2010. Repartición de recursos en dos especies simpátridas de Ameiva (Sauria: Teiidae) en el Parque Nacional Cerros de Amotapes, Tumbes, Perú. Tesis para optar al título profesional de Biólogo. 64 p.
Lehr E. 2002. Amphibien und reptilien in Peru. Natur und Tier Verlag. Münster, Deutschland. p. 236

Linares-Palomino R. 2006. Phytogeography and floristics of seasonally dry forests in Peru. In: R.T Pennington, G.P. Lewis \& J.A. Ratter (Eds.), Neotropical Savannas and Seasonally Dry Forests: Plant Diversity, Biogeography and Conservation. CRC, Boca Raton, FL. p. 257-279.

Mesquita D. \& G. Colli. 2003. The ecology of Cnemidophorus ocellifer (Squamata, Teiidae) in a Neotropical Savanna. Journal of Herpetology. 37(3):498-509

Menezes V.A., Amaral, M.V. Sluys \& C.F.D. Rocha. 2006. Diet and foraging of the endemic lizard Cnemidophorus littoralis (Squamata, Teiidae) in the restinga de Jurubatiba, Macaé, RJ. Brazilian Journal of Biology. 66(3): 803-807.

Pérez J. \& K. Balta. 2009. Dieta de la lagartija de las playas Microlophus peruvianus (Reptilia: Tropiduridae) en la playa Santo Domingo, Ica, Peru. Revista Peruana de Biología. 15(2):129-130

Pérez J. 2005. Ecologia de Duas Espécies de Lagartos Simpatricos em uma Formação Vegetal de Lomas no Deserto Costeiro Peruano Central. Dissertação de Mestrado. Universidade do Estado do Rio de Janeiro (UERJ). Rio de Janeiro. Brasil.

Pianka E. 1973. The structure of lizard communities. Annual Review of Ecology and Systematics, 4: 53-74.

Rocha, CFD. and Siqueira, C. 2008. Feeding ecology of the lizard Tropidurus oreadicus Rodrigues 1987 (Tropiduridae) at Serra dos Carajás, Pará state, northern Brazil. Brazilian Journal of Biology, 68 (1): 109-113

Schoener T.W. 1967. The ecological significance of sexual dimorphism in size in the lizard Anolis conspersus. Science, 155: 474-477

Vitt L., S. Sartorius, T.S. Avila-Pires, M.C. Espósito. 2001. Life at the river's edge: ecology of Kentropyx altamazonica in Brazilian Amazonia. Canadian Journal of Zoology. 79:.1855-1865

Vitt L., S. Sartorius, T.S. Avila-Pires, et al. 2000. Niche segregation among sympatric Amazonian teiid lizards. Oecologia. 122: 410-420.

Vitt, L. J., and P. A. Zani. 1998a. Ecological relationships among sympatric lizards in a transitional forest in the northern Amazon of Brazil. Journal of Tropical Ecology 14:63-86.

Vitt, L. J., and P. A. Zani. 1998b. Prey use among sympatric lizard species in lowland rain forest of Nicaragua. Journal of Tropical Ecology 14:1-23.

Vitt, L. \& P. Zani. 1996. Ecology of the lizard Ameiva festiva (Teiidae) in Southeastern Nicaragua. Journal of Herpetology, 30(1): $110-117$

Vitt, L. \& G. Colli. 1994. Geographical ecology of a Neotropical lizard: Ameiva ameiva (Teiidae) in Brazil. Canadian Journal of Zoology. 72: 1986-2008.

Vitt, L. J., P. A. Zani, J. P. Caldwell, and R. D. Durtsche. 1993. Ecology of the whiptail lizard Cnemidophorus deppii on a tropical beach. Canadian Journal of Zoology 71:2391-2400.

Vitt L., P. Zani, J. Caldwell, \& E. Carrillo. 1994. The ecology of the lizard Kentropyx pelviceps (Sauria:Teiidae) in lowland rainforest of Ecuador. Canadian Journal of Zoology, 73:691-703. 
